Samus Yevhen,

Candidate of Juridical Sciences, Head

of the Research Lab of the State

Research Institute MIA Ukraine, Kyiv,

Ukraine

ORCID ID 0000-0002-8120-0383

\title{
ADMINISTRATIVE AND LEGAL PRINCIPLES AND GUARANTEES OF THE ACTIVITIES OF THE BODIES OF THE SYSTEM MIA UKRAINE FOR THE FULFILLMENT OF FUNCTIONS OF TECHNICAL REGULATION
}

In the paper principles of the fulfillment of functions of technical regulation by bodies of system MIA Ukraine are defined as a system of guiding ideas and fundamental bases of authorized bodies' activities in the field of technical regulation and reflect the most important governance values, which characterize such activities from the perspective of justice, morality and social orientation.

Principles of the fulfillment of functions of technical regulation by bodies of system MIA Ukraine are grouped according to the direction of their influence: 1) constitutional principles, on which any activity in the field of public administration, including technical regulation, is based;2) organizational and procedural principles that determine the manner, in which the respective activity is organized; 3) the functional principles, on which the technical regulation activity is based;4) specialsectoral principles that characterize the peculiarities of the fulfillment of the functions of technical regulation by the bodies MIA Ukraine.

It is substantiated that the guarantees, that ensure the smooth and effective fulfillment of the technical regulation functions by the bodies of the Ministry of Internal Affairs of Ukraine, should include the following: 1) legal guarantees: legal consolidation of jurisdictions, including the fulfillment of coercive measures; coordination of the activity of the bodies of the Ministry of Internal Affairs of Ukraine with higher bodies, etc.; 2) organizational and legal guarantees: guaranteeing of 
unbiased adoption of national standards and codes of practice by consensus; openness of information contained in technical regulations; activity of the Scientific Council, which controls the implementation of scientific and scientific-technical activities, etc.; 3) socio-economic and logistical guarantees: guarantees of an adequate level of remuneration, provision of vacations and other social guarantees for the employees of the Ministry of Internal Affairs of Ukraine, including those directly implementing the functions of technical regulation; provision of necessary equipment, machinery and other equipment for research and development, testing, etc.

Keywords: systems of bodies MIA Ukraine, technical regulation, standartization, functions of technical regulation, principles, guarantees.

\section{REFERENCES}

1. Koteniov O.H. (2013) Do poniattia pryntsypiv prava pryrodokorystuvannia. "About the Concept of the Principles of Environmental Law". Law and Security 4, P. 162-167. [in Ukrainian].

2. Hryshchuk O.V. (2015) Pryntsypy prava: filosofsko-pravovyi vymir. "Principles of Law: Philosophical and Legal Dimension". Bulletin of the University of Lviv. Vol. 61. P. 16-23. [in Ukrainian].

3. Maksimentseva N.O. (2017) Spivvidnoshennia pryntsypiv administratyvnoho prava ta pryntsypiv derzhavnoho upravlinnya. "Correlation of Principles of Administrative Law and Principles of Public Administration". Entrepreneurship, Economy and Law 5, P. 115-118. [in Ukrainian].

4. Vynohradova N.L. (2006) Suchasni pidkhody do systematyzatsii pryntsypiv $\mathrm{u}$ teorii derzhavnoho upravlinnia $\mathrm{v}$ konteksti zmistovnoho analizu ponIattia «pryntsyp». "Modern Approaches to the Systematization of Principles in the Theory of Public Administration in the Context of Meaningful Analysis of the Concept of "Principle". Master 1 (27), 201-203 [in Ukrainian].

5. Derzhavne upravlinnia. "Public Administration": Educ. Manual/ A.F. Melnyk, O.Yu. Obolensky, A.Yu. Vasina, L.Yu. Hordienko; ed. A.F. Melnik. Kyiv: Knowledge-Press, 2003. 343 p. [in Ukrainian]. 
6. On the National Police: Law of Ukraine dated 02.07.2015 No 580-VIII. URL: http://zakon5.rada.gov.ua/laws/show/580-19 (date of application: 29.09.2019) [in Ukrainian].

7. Vitkin L.M. (2013) Svitovyi dosvid ta stratehiia rozvytku system tekhnichnoho rehuliuvannia. "World Experience and Strategy for the Development of Technical Regulation Systems”. Standardization. Quality. Certification 4, P. 3-1. [in Ukrainian].

8. On Standardization: Law of Ukraine dated 05.06.2014 No 1315-VII. URL : http://zakon3.rada.gov.ua/laws/show/1315-18 (date of application: 29.09.2019) [in Ukrainian].

9. Harust Yu.V. (2014) Poniattia ta oznaky harantii zabezpechennia prav hromadian u podatkovii sferi. "Concepts and Features of Guarantees for Ensuring Citizens' Rights in the Tax Sphere". Forum Prava 2, P. 76-80. [in Ukrainian].

10. Komziuk V.T. (2015) Pravovi harantii diialnosti mytnykh orhaniv Ukrainy. "Legal Guarantees of Activity of Customs Authorities of Ukraine". Law and Security 2 (57), P. 70-74 [in Ukrainian].

11. Nahornyi O.P. Zakonnist $\mathrm{v}$ administratyvnii diialnosti orhaniv vnutrishnikh strav ta shliakhy yii udoskonalennia. "Legality in the Administrative Activity of the Bodies of Internal Affairs and Ways of Its Improvement": abstract of a thesis. ... Cand. of Jurid. Sciences: 12.00.07. Kyiv, 2003. 22 p. [in Ukrainian]. 